\title{
Development of a Solar Dryer Incorporated with a Thermal Storage Mechanism
}

\author{
Lasisi O.I ${ }^{1}$, Fapetu O.P. ${ }^{2}$, Akinola A.O. ${ }^{3}$ \\ ${ }^{1}$ Department of Mechanical Engineering, Waziri Umaru Federal Polytechnic, Birnin, Kebbi State. \\ ${ }^{2-3}$ Department of Mechanical Engineering, The Federal University of Technology Akure, Ondo State.
}

Nigeria

\begin{abstract}
This work presents the development and performance evaluation of a solar crop dryer for drying agricultural products. The dryer consists of three major parts; the drying chamber ( $630 \mathrm{~mm}$ by $610 \mathrm{~mm}$ by $210 \mathrm{~mm})$, a solar collector ( $630 \mathrm{~mm}$ by 590 $\mathrm{mm}$ by $50 \mathrm{~mm})$ and a heat storage device $(630 \mathrm{~mm}$ by $590 \mathrm{~mm}$ by $50 \mathrm{~mm})$. The dryer was designed for crops weighing a maximum of $15 \mathrm{~kg}$ with an ambient temperature of $33 \mathrm{oC}$. The performance evaluation was carried out using unripe plantain and okra. The results of the performance evaluation for no-load test showed that the average temperatures for the drying chamber, collector and ambient without the heat storage system and the boaster mirror were recorded as 47,69 and $32^{\circ} \mathrm{C}$ respectively and $55.5,71.5$ and $32^{\circ} \mathrm{C}$ with heat storage, while $73^{\circ} \mathrm{C}, 83.5^{\circ} \mathrm{C}, 32^{\circ} \mathrm{C}$ respectively with both the heat storage and boaster mirror. The boaster mirror introduction recorded a higher temperature of $73^{\circ} \mathrm{C}$ in the drying chamber as against $55.5^{\circ} \mathrm{C}$ when it was not installed. The results of the on-load test shows that the rate of moisture removal was faster in the dryer (1 to 0.24) $\mathrm{kg}$ after drying for four days fro plantain and (1 to 0.21) $\mathrm{kg}$ after drying for three days for okra as against (1 to 0.35) $\mathrm{kg}$ for plantain and (1 to 0.49) $\mathrm{kg}$ for okra with direct/open sun drying. The products were evaluated for physicochemical properties for the fresh, solar dryer dried and open sun-dried samples and results shows that solar-dried plantain and okra recorded higher percentage of nutrients over open sun-dried samples in Fibre, protein, ash content (1.89, $1.17,0.39),(1.63,1.14,1.53)$ respectively, while the percentage of fat content was significantly higher in sun-dried samples with plantain having $(0.32 \%)$ and okra $(0.1 \%)$ as against solar-dried samples.
\end{abstract}

Keywords: Solar Energy, Dryer, Storage Mechanism, Performance Evaluation, Proximate Analysis.

\section{INTRODUCTION}

Food crop production is of great importance to the growth and sustainability of any nation and its citizens. Crops and vegetables as sources of food intake are of great nutritional and health importance to every living thing, since they make significant contribution in supplying essential protein, minerals, vitamins and antioxidant that improve the quality of the diet and constitute a health benefits for the consumers. These components are known to fight harmful free radicals that are associated with cancer and other life threatening diseases [1-2]. However, according to [3], fresh crops and fruits are not only seasonal but highly perishable simply because their moisture contents are between $20-95 \%$. It was estimated that $50 \%$ of the crops in the developing countries are lost after harvest because of inefficient handling and poor implementation of post-harvest technology.

The Food and Agricultural Organisation [4] reported that the world production of fruits and crops over a five-year period (1999 - 2004) was 489 million tons for vegetables and 448 million tons for fruits [4]. This trend increased as expected, reaching a global production of 508 million tons for vegetables and 469 tons for crops in 2004. This trend of production is expected to increase at a rate of 3.2 percent per year for vegetables and 1.6 percent per year for fruits. However, little considerations and attention are given to preservation aspect of this important agricultural produce in Nigeria.

One major means of preservation of agricultural produce is by drying. Sun drying is one of the oldest traditional methods that use solar energy to dry produces such as vegetables, fruits, fish, crops and meat by exposing them directly to the sun. It 
is a simple process of removing the moisture contents from a natural or industrial product in order to reach the standard specification. [5]. According to [6] two types of water are present in food items; the chemically bound water and the physically held water. In drying, it is only the physically held water that is removed. The most important reasons for the popularity of dried products are longer shelf life, product diversity as well as substantial volume reduction. This could be expanded further with improvements in product quality and process applications.

Sun drying has many disadvantages such as spoilt products due to rain, wind, dust, insect infestation, animal attack and fungi growth. In order to improve traditional drying method, the solar dryer technology will become an alternative method that can be used to process the products in clean, safe, hygienic and produce better quality and more nutritious foods. The solar dryer can be seen as one of the solutions to the world's food and energy crises. With drying, most agricultural produce can be preserved and this can be achieved more efficiently through the use of solar dryers. Solar dryers are a very useful device for: Dairy industries for production of milk powder, food processing industries for dehydration of fruits and vegetables, seasoning of wood and timber, fish and meat drying, textile industries for drying of textile materials, Agricultural crop drying, etc. Thus, solar dryer is one of the many ways of making use of solar energy efficiently in meeting man's demand for energy and food supply.

Solar drying can be classified into direct, indirect and mixed-modes. In direct solar dryers the air heater contains the materials and solar energy passes through a transparent cover and is absorbed by the materials. Essentially, the heat required for drying is provided by radiation to the upper layers and subsequent conduction into the material bed. In indirect dryers, solar energy is collected in a separate solar collector (air heater) and the heated air then passes through the material bed, while in the mixed-mode type of dryer, the heated air from a separate solar collector is passed through a material bed and at the same time, the drying cabinet or chamber absorbs solar energy directly through the transparent walls or roof [7].

Energy balance on a flat plate collector:

According to [8], the energy balance on a flat collector can be obtained by equating the total heat gained to the total heat loosed by the heat absorber of the flat plate collector. This is given in equation (1)

$\tau \mathrm{I}_{\mathrm{T}} \mathrm{Ac}=\mathrm{Q}_{\mathrm{U}}+\mathrm{Q}_{\mathrm{K}}+\mathrm{Q}_{\mathrm{C}}+\mathrm{Q}_{\mathrm{R}}+\mathrm{Q} \rho$,

where

$\mathrm{I}_{\mathrm{T}}=$ rate of total radiation incident on the absorber's surface $\left(\mathrm{Wm}^{-2}\right)$;

$\mathrm{Ac}=$ the collector area $(\mathrm{m})$;

$\mathrm{Q}_{\mathrm{U}}=$ rate of useful energy collected by the air

(W);

$\mathrm{Q}_{\mathrm{K}}=$ rate of conduction losses from the absorber $(\mathrm{W})$;

$\mathrm{Q}_{\mathrm{C}}=$ rate of convective losses from the absorber $(\mathrm{W})$;

$\mathrm{Q}_{\mathrm{R}}=$ rate of long wave re-radiation from the absorber $(\mathrm{W})$;

$\mathrm{Q} \rho=$ rate of reflection losses from the absorber $(\mathrm{W})$.

$\tau=$ transmittance of the top glazing and

The three heat loss terms $\mathrm{Q}_{\mathrm{K}}, \mathrm{Q}_{\mathrm{C}}$ and $\mathrm{Q}_{\mathrm{R}}$ are usually combined into one-term $(\mathrm{Q})_{\mathrm{L}}$. i.e.

$\left.\mathrm{Q}_{\mathrm{L}}=\mathrm{Q}_{\mathrm{K}}+\mathrm{Q}_{\mathrm{C}}+\mathrm{Q}_{\mathrm{R}}\right)(\mathrm{W})$

where

$\mathrm{Q}_{\mathrm{L}}=$ combined rate of heat losses $(\mathrm{W})$

The reflected energy from the absorber is given by equation (3). [9]

$\mathrm{Q}_{\mathrm{R}}=\tau \mathrm{I}_{\mathrm{T}} \mathrm{Ac} \rho$

where

$\rho=$ reflection coefficient of the absorber.

Putting equation (2), (3) into equation (1), the following expression is obtained for the useful energy.

$\mathrm{Q}_{\mathrm{u}}=\tau \mathrm{A}_{\mathrm{c}}(\mathrm{I}-\rho) \mathrm{I}_{\mathrm{T}}-\mathrm{Q}_{\mathrm{L}}$

For an absorber, $(1-\rho)=\alpha$. Therefore,

where

$\alpha=$ absorptivity of transparent surface.

When the flat plate collector is exposed to solar radiation its temperature rises, heat energy is lost through the top mainly by convection and radiation; and through the bottom and side panels by conduction. This is giving by equation (5) [8]:

$\mathrm{Q}_{\mathrm{L}}=\mathrm{U}_{\mathrm{L}} \mathrm{A}_{\mathrm{C}}\left(\mathrm{T}_{\mathrm{c}-\mathrm{T}_{\mathrm{a}}}\right)$

where

$\mathrm{U}_{\mathrm{L}}=$ overall heat transfer coefficient of the absorber $\left(\mathrm{W}^{-2} \mathrm{~m}^{-1} \mathrm{~K}\right)$; 
Ac $=$ collector area $\left(\mathrm{m}^{2}\right)$

$\mathrm{T}_{\mathrm{c}}=$ temperature of the collector's absorber $\left({ }^{\circ} \mathrm{C}\right)$;

$\mathrm{T}_{\mathrm{a}}=$ ambient air temperature $\left({ }^{\circ} \mathrm{C}\right)$.

From Equations (2) and (3) energy gained by the collector is given by equation (6)

$\mathrm{Q}_{\mathrm{u}}=(\alpha \tau) \mathrm{I}_{\mathrm{T}} \mathrm{Ac}-\mathrm{U}_{\mathrm{L}} \mathrm{A}_{\mathrm{C}}\left(\mathrm{T}_{\mathrm{c}}-\mathrm{T}_{\mathrm{a}}\right)$

Therefore, the energy per unit area $\left(q_{u}\right)$ of the collector is given in equation $(7)$

$\mathrm{q}_{\mathrm{u}}=(\alpha \tau) \mathrm{I}_{\mathrm{T}}-\mathrm{U}_{\mathrm{L}}\left(\mathrm{T}_{\mathrm{c}}-\mathrm{T}_{\mathrm{a}}\right)$

Hence, the thermal efficiency of the collector is given by equation (8)

$\eta_{\mathrm{c}}=\frac{\mathrm{q}_{\mathrm{u}}}{\mathrm{I}_{\mathrm{T}}}$

This can be rewritten as:

$\eta_{\mathrm{c}}=\eta_{\mathrm{o}}-\frac{\mathrm{U}_{\mathrm{L}}}{\mathrm{I}_{\mathrm{T}}}\left(\mathrm{T}_{\mathrm{c}}-\mathrm{T}_{\mathrm{a}}\right)$.

where

$\eta_{\mathrm{o}}=(\alpha \tau)$; the net transmissivity absorptivity product often termed as the optical efficiency of the conversion factor.

The required collector area is given by [9] as:

$$
\mathrm{A}_{\mathrm{c}}=\frac{\mathrm{q}_{\mathrm{u}}}{\mathrm{I}_{\mathrm{T}} \mathrm{1}_{\mathrm{c}}}
$$

The sensible heat Qst stored by the asphalt was established using equation (11) [10],

$$
\mathrm{Q}_{\mathrm{s}}=\rho_{\mathrm{s}} \mathrm{v} \mathrm{C}_{\mathrm{p}}\left(\mathrm{T}_{\mathrm{s}-} \mathrm{T}_{\mathrm{m}}\right)
$$

where

Qs $=$ heat stored $(\mathrm{W})$

$\rho_{\mathrm{s}}=$ density of storage medium $\left(\mathrm{kg} / \mathrm{m}^{3}\right)$

$\mathrm{V}=$ volume of container $\left(\mathrm{m}^{3}\right)$

$c_{p}=$ specific heat of medium $\left(\mathrm{kJkg}^{-1} \mathrm{~K}^{-1}\right)$

$\mathrm{T}_{\mathrm{a}}=$ storage temperature $\left({ }^{\circ} \mathrm{C}\right)$

$\mathrm{T}_{\mathrm{m}}=$ minimum useful temperature $\left({ }^{\circ} \mathrm{C}\right)$

The moisture loss is given by equation (12) [11]

$\mathrm{ml}=\mathrm{m}_{1}-\mathrm{m}_{2}(\mathrm{~kg})$

where, $\mathrm{m}_{1}$ is the mass of the sample before drying, $\mathrm{m}_{2}$ is the mass of sample after drying

Percentage (\%) of moisture content (m.c.): This is given by equation (13)

$\mathrm{m} \cdot \mathrm{c}=\frac{\left(\mathrm{M}_{1}-\mathrm{M}_{2}\right)}{\mathrm{M}_{1}} \times \frac{100}{1}$

where, $\mathrm{m}_{1}$ is the mass of the sample before drying, $\mathrm{m}_{2}$ is the mass of sample after drying

Dryer efficiency $\left(\eta_{d}\right)$ : This was obtained using equation (14)

$\eta_{\mathrm{d}}=\frac{\text { work output }}{\text { work input }} \times \frac{100}{1}$

where (work output) is the final mass of the sample after drying and (work input) is initial mass of the sample before drying. where $\mathrm{m}_{1}$ is the mass of sample before drying and $\mathrm{m}_{2}$ is the mass of sample after drying.

\section{METHODS AND MATERIAL}

The following reasons were considered in selecting materials for the construction of the passive solar food dryer.

i. The ability of the materials to withstand service conditions

ii. The overall cost and availability of the material 


\subsection{Components of the Dryer}

The dryer is made up of three main parts

i. Drying chamber

ii. Solar collector

iii. Solar store.

\subsection{Drying Chamber}

This is the section where crop drying processes takes place. It is constructed with an external frame of wood 20 mm thick, insulated with $20 \mathrm{~mm}$ polystyrene foam on all the sides and the base. The inner wall was constructed with a galvanize metal sheet and painted with black. Both sides of the chamber were fixed with a transparent glass for solar radiation penetration. The chamber consist of a tray measuring $580 \mathrm{~mm}$ x $580 \mathrm{~mm}$ x $40 \mathrm{~mm}$, it has a hot air outlet, which is located at the upper part of the chamber. This provision allows moist air evaporated from the food to escape into the surrounding. The roof of the dryer is cover with aluminum glass frame of size $670 \mathrm{~mm}$ x $660 \mathrm{~mm}$ x $34 \mathrm{~mm}$ inclined at $7.25^{\circ}$ (the latitude of Akure). This allows direct solar radiation into the chamber thereby enhancing food drying operation. A mirror of $4 \mathrm{~mm}$ thickness house by plywood of size $690 \mathrm{~mm}$ x $670 \mathrm{~mm}$ x $90 \mathrm{~mm}$ was fixed at the upper back of the dryer as a reflector. This is manually operated by tracking the radiation from the sun and reflecting it on the transparent cover of the drying chamber.

\subsection{Solar collector}

The solar collector was fabricated from galvanize sheet metal $(640 \mathrm{~mm}$ x $440 \mathrm{~mm})$ painted black. It (collector plate) was house by a wooden box of dimension $(680 \mathrm{~mm}$ x $480 \mathrm{~mm}$ x $100 \mathrm{~mm}$ ). The wooden box of $20 \mathrm{~mm}$ thickness and $20 \mathrm{~mm}$ polystyrene foam served as an insulator while the bottom base was constructed using plywood of 20 mm thickness and 20 $\mathrm{mm}$ polystyrene foam were used for the insulator. The wooden box was covered with a transparent glass cover made of a aluminum frame of size $670 \mathrm{~mm}$ x $470 \mathrm{~mm} 34 \mathrm{~mm}$. A space of $50 \mathrm{~mm}$ between the plate and the glass were provided, this will allow the incoming air to be heated and passes through an air passage created between the top and bottom of the wooden box. The wavelength rage of the incoming solar spectrum is less than $3 \mu \mathrm{m}$ for all than about $2 \%$ of the total incoming solar energy outside the earth's atmosphere. When this radiation reaches the collector glazing, as much as $90 \%$ can be transmitted directly, the remainder being reflected or absorbed by the glass. The absorbed energy raises the temperature of the glass so that, in turn the glass radiated from both internal and external surfaces. As the surface temperature of the collector plate rises, it also radiates but at a very small proportion of the total energy, typically less than $1 \%$ for a black surface at $100^{\circ} \mathrm{C}$. The long wave radiation emitted by the collector plate cannot pass back directly through the glass, as the transmittance of the glass is practically zero in the range of $3-50 \mu \mathrm{m}$. This process is the greenhouse effect and the use of transparent cover greatly reduces heat losses from the collector [9]. When short wavelength solar radiation falls on the solar collector, it penetrate the transparent glazing cover and is converted to low-grade heat, the energy radiates on a long wavelength that cannot pass back through the cover. Figure 1 shows a typical solar radiation processes taking place in the dryer.

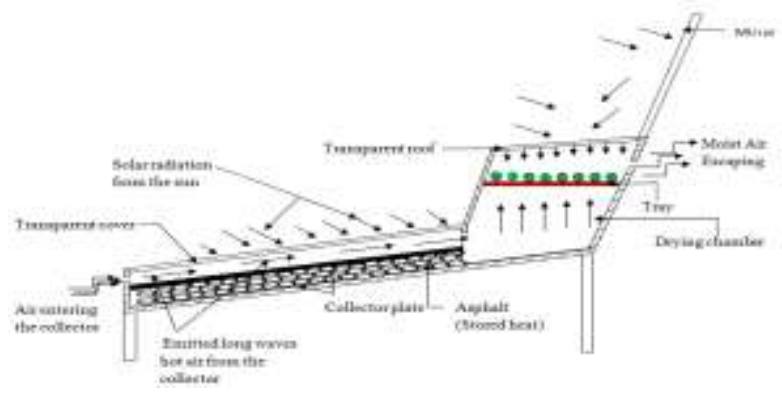

Figure:1 Typical solar radiation processes in the passive solar drying during the day

\subsection{Solar heat storage unit}

The heat storage unit is an integral part of the solar collector. The solar heat storage unit was made to be under the collector plate. This losses heat to the plate when the environmental is colder, and thus enhance off sun drying. A typical heat transfer processes taking place during the night from the solar heat storage unit is represented in Figure 2 


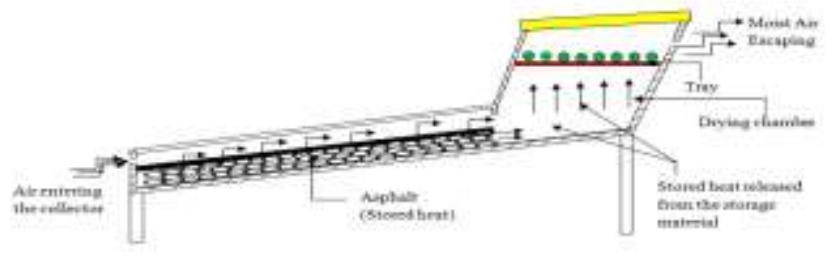

FIGURE :2 Solar stored device releasing stored heat during the night

\subsection{Drying tray}

A galvanize wire-mesh was use as tray where the food to dried is kept. The wire-mesh contained holes; these holes are to allow air movement, and moisture drainage. It has advantage of absorbing heat and transferring such heat to the food, thus contributing positively to the drying process.

\subsection{Reflector Mirror}

A reflector mirror of $4 \mathrm{~mm}$ was provided as a boaster to reflect an incident radiation ray from the sun on the drying chamber glazing. The rays from the mirror served as an additional rays being reflected on the drying chamber glazing apart from the direct solar radiation from the sun. This is to further increase the drying rate in the chamber.

\subsection{Solar Storage Material}

Commonly used sensible materials in this regard are asphalt, pebble, concrete, rock. For this design asphalt was used. Asphalt happens to be black and it has an extremely high absorbtivity and emissivity of solar energy. It was reported by [12] that asphalt can absorb 80 to $90 \%$ of solar radiation from the sun and released this in the night.

\subsection{Collector's Tilt Angle}

The position of the sun, the declination angle plays an important role in the performance of solar collectors [8].There is an optimum angle of declination through which the collector will collect more energy per unit area than when vertical or horizontal. The Angle of declination changes with time of the year, but there is angle of inclination (tilt angle: the Angle between collector and horizontal plane) for which the energy collected can be maximize.

The best means of collecting solar energy is for the absorber to follow (track) the sun, but this method is very expensive, the cost effective method is a stationary orientation, due south in the northern hemisphere and due north in the southern hemisphere. In this situation, the angle between the collector and the horizontal plane is often taken to be equal to the latitude of the place. However, different angles such as $10^{\circ}$ greater than the latitude $\left(23.5^{\circ}\right)$ greater than the latitude, and 1.5 times the latitude have been recommended. However, the best all year round performance is obtained with a stationary absorber facing the south when inclined to the horizontal at about $10^{\circ}$ more than the local geographical latitude. [13]. Akure is on latitude $7.25^{\circ} \mathrm{N}$, Longitude $5.195^{\circ} \mathrm{E}$. Using the best all year round performance orientation, the design tilt angle is about $17.25^{\circ}$ to the horizontal.

\subsection{Performance Evaluation of the Dryer}

The passive solar dryer was incorporated with heat storage device to continue the drying when the ambient temperature drops to the minimum. To ascertain whether the dryer's temperature could be high enough to dry the crop, the booster mirror and the empty (unloaded) dryer's temperature without heat storage was measure at every 1 hour for the no-load test and also tested without the booster mirror to ascertain the effect of the booster mirror. The dryer was tested with both samples of unripe plantain and okro with both the booster mirror and heat storage device. These were conducted simultaneously with open sun drying as a control. Both samples were weigh in the morning before drying and in the evening using a weighing balance and the moisture content was calculated from the weight loss. The processes were monitored and readings were taking for both drying temperature and ambient by using thermometer while moisture loss was taking by using weighing balance until the crops were dried.

\section{RESULTS AND DISCUSSION}

\subsection{On no - load}

Figure 3 shows average temperature against time of unloaded dryer, collector and ambient. At an average ambient temperature of $31.5^{\circ} \mathrm{C}$, the dryer recorded its highest temperature of $50.5^{\circ} \mathrm{C}$ at a collector temperature of $69^{\circ} \mathrm{C}$. The higher temperature in the dryer could be attributed to the fact that all the heat transferred to the dryer were not used for drying. This agreed with the work of [9] that the drying chamber on no-load had a high temperature.

Figure 4 shows average temperature against time of unloaded dryer, collector and ambient with the incorporated heat storage system. It was observed that the dryer and collector temperatures were higher between the hours of (12.00 am - 
$2.00 \mathrm{pm}),(50,55.5,53.5)^{\circ} \mathrm{C}$ and $(70,71,65.5)^{\circ} \mathrm{C}$ respectively. The higher temperature in the collector was as a result of the incorporated heat storage system because the heat stored also releases part of the heat stored on the collector plate. Figure 5 shows average temperature of unloaded dryer against time with both heat storage system and boaster mirror. At an ambient temperature of $32{ }^{\circ} \mathrm{C}$, the dryer recorded its highest temperature of $73^{\circ} \mathrm{C}$ at a collector temperature of $83.5^{\circ} \mathrm{C}$. The higher temperature recorded in the dryer could be attributed to the introduction of the reflector mirror; parts of the incident rays on the reflector mirror are reflected on the transparent cover on the drying chamber thereby increasing the heat in the chamber.

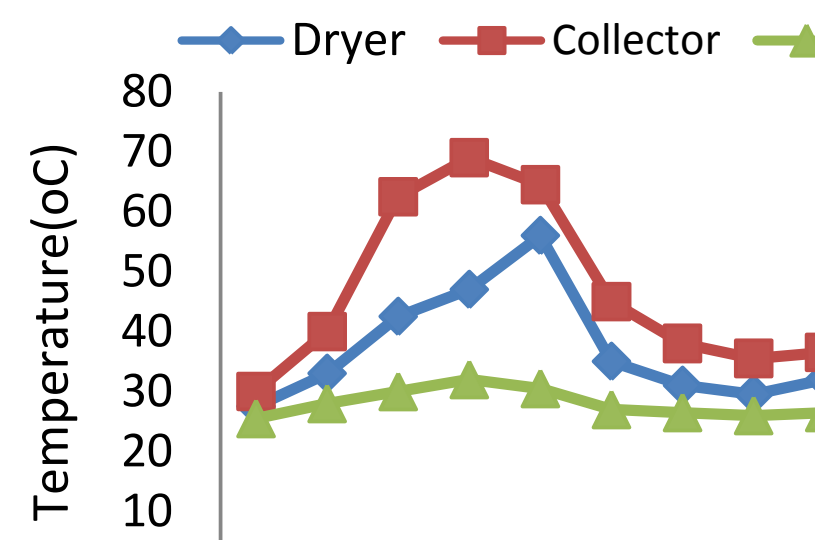

Fig: 3 Graph of Average unloaded chamber, collector and ambient without heat storage system and boaster mirror for 2 days
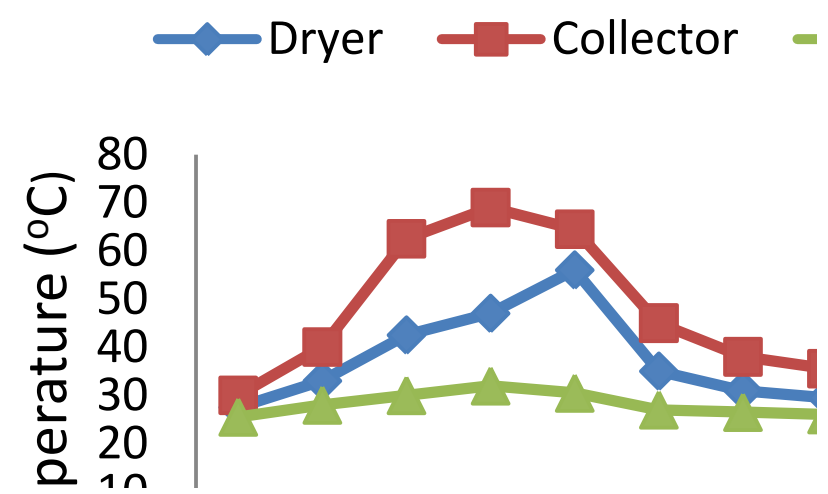

Fig: 4 Graph of Average unloaded solar dryer, collector and ambient with heat storage system for 2 days

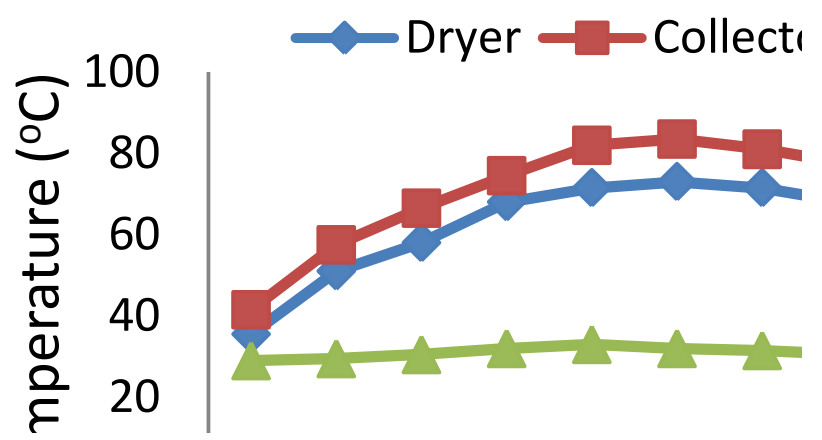

Fig: 5 Graph of Average Temperature of unloaded solar dryer, collector and ambient with heat storage system and boaster mirror for 2 days 


\subsection{On load}

\section{With unripe plantain}

Unripe plantain was used to test the dryer, while open sun drying was use as the control which was set up in the open. Plantain of $2 \mathrm{~kg}$ was cut into the same equal size and divided into equal half, each half was spread on two separate trays one for the dryer and other for sun drying. The weights were measured two times a day (in the morning at the beginning of test and in the evening at the end of the day's test). It took the plantain four days to dry to the required moisture level of $15 \%$ from $90 \%$, during which the sun dry experiment serve as control was still about $7.5 \%$ above the level.

Figures 6 to 9 shows temperature profiles for plantain for four days. It was observed that the dryer attained maximum temperature of $75^{\circ} \mathrm{C}$ with a maximum efficiency of $62 \%$ for the first day as against ambient temperature of $33^{\circ} \mathrm{C}$. The dryer performed a lot better than the domestic passive solar dryer as reported by [14] when tested with plantain. While the solar dryer incorporated with both the heat storage device and the boaster mirror recorded a maximum temperature of $75^{\circ} \mathrm{C}$ and efficiency of $62 \%$ in which he recorded a maximum drying temperature of $50.50^{\circ} \mathrm{C}$ and efficiency of $59.13 \%$.

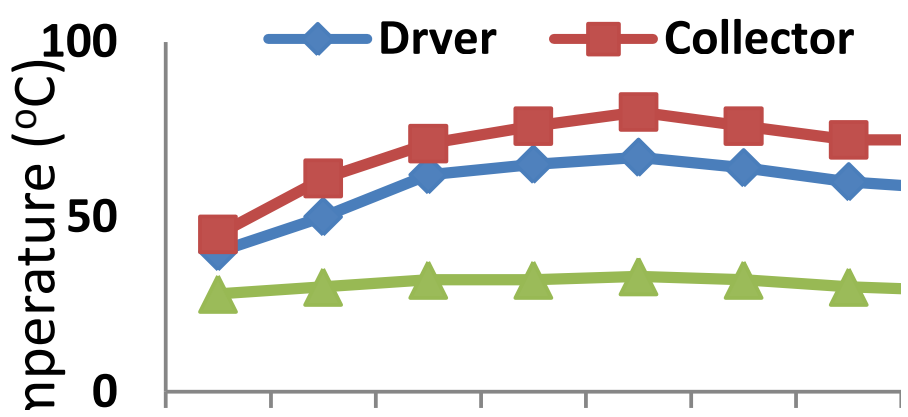

Fig: 6 Temperature of loaded solar dryer, collector and ambient with heat storage system and the boaster mirror for (Plantain) Day 1

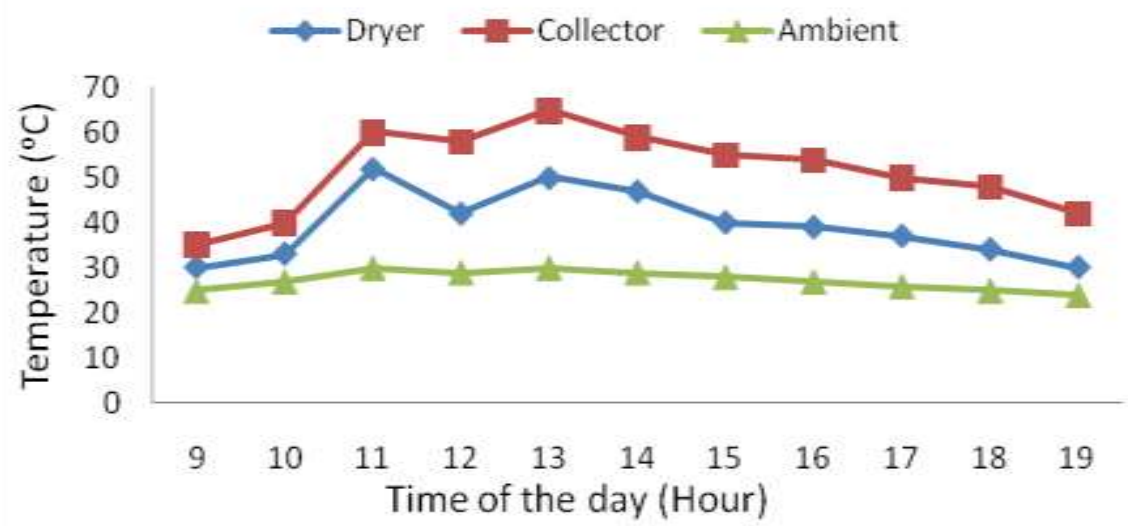

Fig: 7 Temperature of loaded solar dryer, collector and ambient with heat storage system and the boaster mirror for (Plantain) Day 2

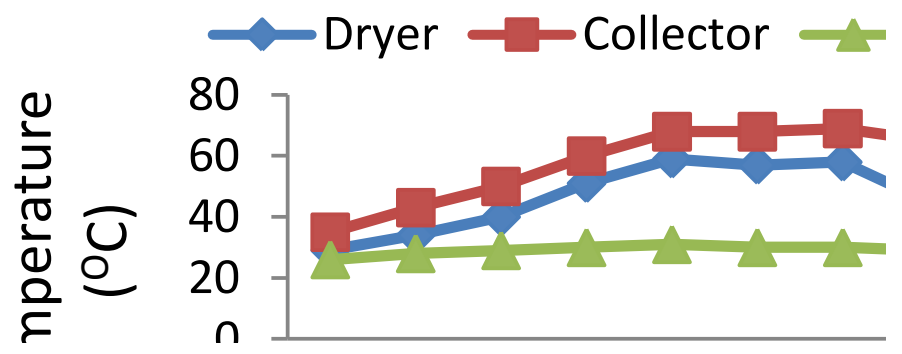

Fig: 8 Temperature of loaded solar dryer, collector and ambient with heat storage system and the boaster mirror for (Plantain) Day 3 


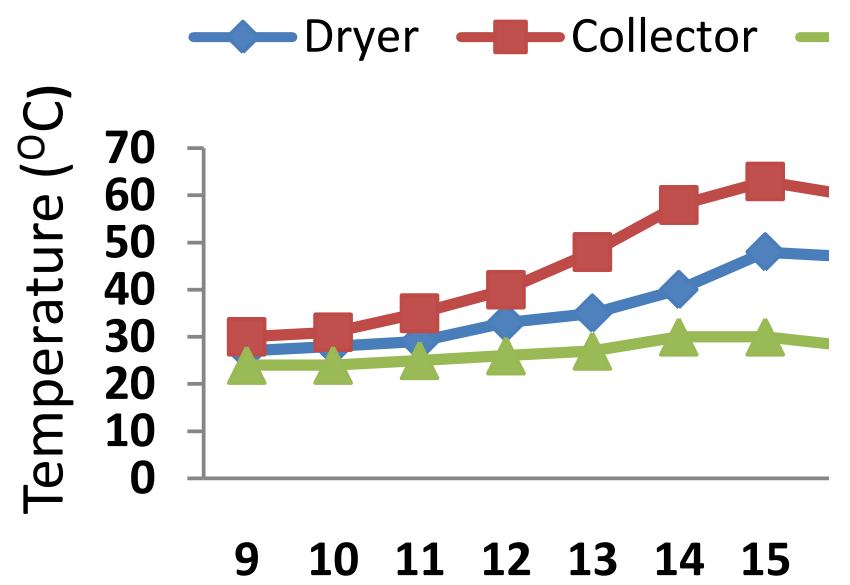

Fig: 9 Temperature of loaded solar dryer, collector and ambient with heat storage system and the boaster mirror for (Plantain) Day

\subsection{Testing With okra}

Okra was used to test the dryer, while open sun drying was use as the control which was set up in the open. Okra of $2 \mathrm{~kg}$ was cut into the same

equal size and divided into equal half, each half was spread on two separate trays one for the dryer and other for sun drying. The weights were measured two times a day (in the morning at the beginning of test and in the evening at the end of the day's test). The temperature profile is shown in Figures 10 to 12 . The highest collector temperature of $84^{\circ} \mathrm{C}$ was recorded in the first day at an ambient temperature of $33^{\circ} \mathrm{C}$, and dryer temperature of $70^{\circ} \mathrm{C}$ with efficiency of $69 \%$. The solar dryer performed much better with temperature values of $70^{\circ} \mathrm{C}$ as compare to mixe-mode solar dryer as recorded by [3] when drying with okra. The mixe-mode dyer recorded an average drying temperature of $65.6^{\circ} \mathrm{C}$ and ambient temperature of $36.6^{\circ} \mathrm{C}$ during the raining season while $66.5^{\circ} \mathrm{C}$ and $34.34^{\circ} \mathrm{C}$ was recorded during the dry season.

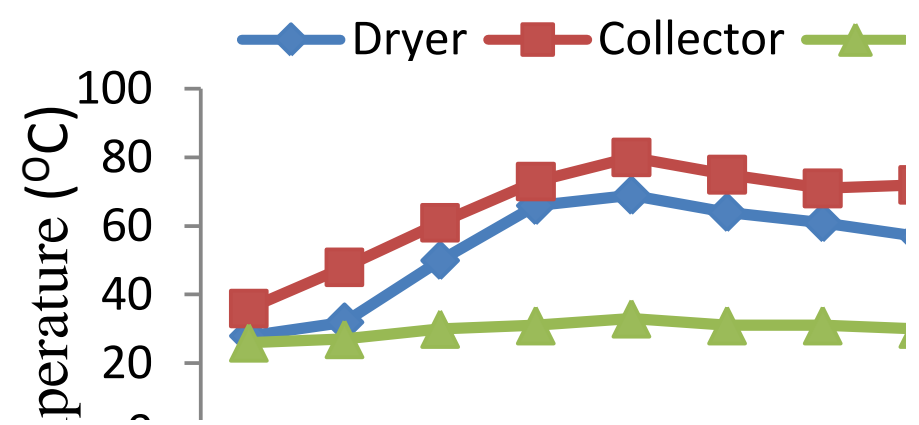

Fig: 10 Temperature of loaded solar dryer, collector and ambient with heat storage system and the boaster mirror for (Okra) Day 2

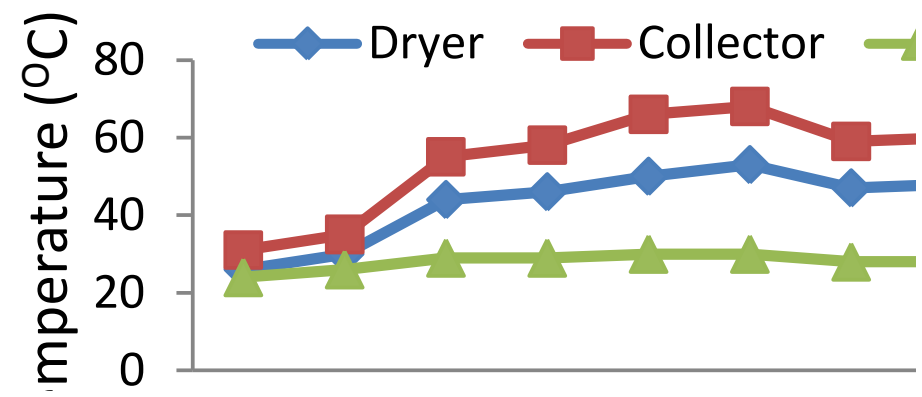

Fig: 11 Temperature of loaded solar dryer, collector and ambient with heat storage system and the boaster mirror for (Okra) Day 2 


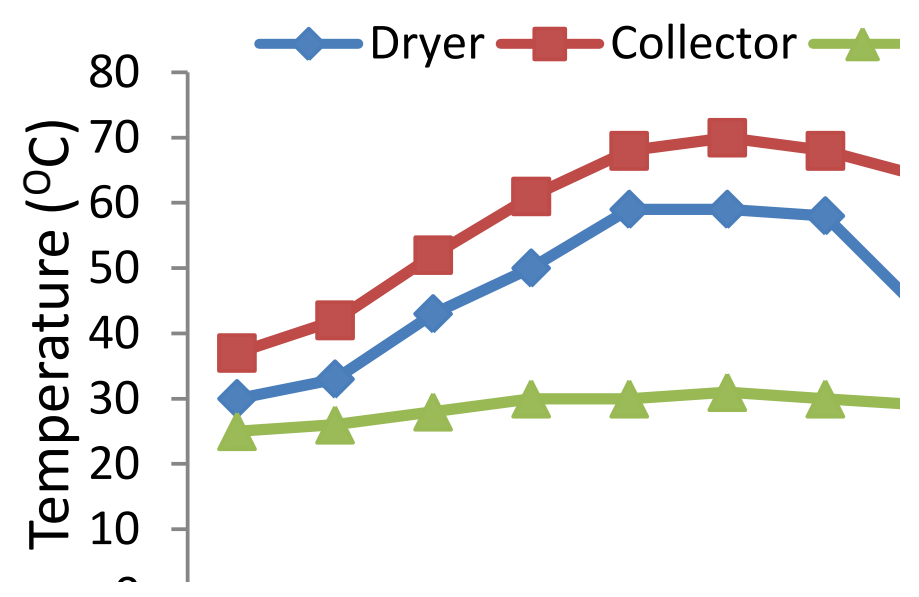

Figure: 12 Temperature of loaded solar dryer, collector and ambient with heat storage system and the boaster mirror for (Okra) Day 3

\subsection{Heat Retention Test}

The dryer was tested during the nights to evaluate its heat retention ability. Each morning, the weight of the plantain and Okra in the dryer was found to have reduced. This was attributed to heat being evolved from the heat stored, while that in the open sun gained weight. A typical example was on the first day of drying plantain the weight of sample at 19.00 hours was $0.63 \mathrm{~kg}$, this had reduced to $0.62 \mathrm{~kg}$ at 09.00 hours of the second day (Table 1) as against open sun drying which increases from $0.85 \mathrm{~kg}$ to $0.855 \mathrm{~kg}$. Consequently, the thermal storage system performed and maintained a moderate heat in the night for both samples and ensure continuity, the readings are presented in Table 2 and 3 for both plantain and okra respectively.

Table 1 Moisture removed on each day for plantain for both Dryer and control

\begin{tabular}{|l|l|l|l|l|l|l|}
\hline \multirow{2}{*}{ Day } & \multicolumn{3}{|l|}{ Dryer } & \multicolumn{3}{l|}{ Control } \\
\cline { 2 - 7 } & $\begin{array}{l}\text { WBD } \\
(\mathrm{kg})\end{array}$ & $\begin{array}{l}\text { WAD } \\
(\mathrm{kg})\end{array}$ & $\begin{array}{l}\text { Moisture } \\
(\%)\end{array}$ & $\begin{array}{l}\text { WBD } \\
(\mathrm{kg})\end{array}$ & $\begin{array}{l}\text { WAD } \\
(\mathrm{kg})\end{array}$ & $\begin{array}{l}\text { Moisture } \\
(\%)\end{array}$ \\
\hline 0 & 1.00 & 1.00 & 90 & 1.00 & 1.00 & 90 \\
\hline 1 & 1,00 & 0.62 & 52 & 1.00 & 0.85 & 75 \\
\hline 2 & 0.615 & 0.41 & 31.5 & 0.855 & 0.70 & 59.5 \\
\hline 3 & 0.405 & 0.290 & 20 & 0.71 & 0.55 & 43.5 \\
\hline 4 & 0.290 & 0.240 & 15 & 0.56 & 0.35 & 22.5 \\
\hline 5 & & & & 0.37 & 0.295 & 15 \\
\hline
\end{tabular}

WBD - Weight before drying and WAD - Weight after drying for the day

Table: 2 Dryer with Thermal Store for Plantain (Day 1)

\begin{tabular}{|l|l|l|l|l|}
\hline $\begin{array}{l}\text { Time } \\
\text { (Hours) }\end{array}$ & $\begin{array}{l}\mathbf{T}_{\mathbf{S}} \\
\left({ }^{\mathbf{0}} \mathbf{C}\right)\end{array}$ & $\mathbf{T}_{\mathbf{a}}\left({ }^{\mathbf{0}} \mathbf{C}\right)$ & $\begin{array}{l}\text { Relative } \\
\text { Humidity } \\
(\text { ambient }) \\
(\%)\end{array}$ & $\begin{array}{l}\text { Relative } \\
\text { Humidity } \\
(\text { dryer }) \\
(\%)\end{array}$ \\
\hline 8.00 & 29 & 26 & 75 & 70 \\
\hline 2.00 & 33 & 24 & 85 & 60 \\
\hline 21.00 & 32 & 24 & 85 & 65 \\
\hline
\end{tabular}


Table 3 Dryer with Thermal Store for Okra (Day1)

\begin{tabular}{|l|l|l|l|l|}
\hline $\begin{array}{l}\text { Time } \\
\text { (Hours) }\end{array}$ & $\begin{array}{l}\mathrm{T}_{\mathrm{S}} \\
\left({ }^{\circ} \mathrm{C}\right)\end{array}$ & $\mathrm{T}_{\mathrm{a}}\left({ }^{\circ} \mathrm{C}\right)$ & $\begin{array}{l}\text { Relative } \\
\text { Humidity } \\
(\text { ambient }) \\
(\%)\end{array}$ & $\begin{array}{l}\text { Relative } \\
\text { Humidity } \\
(\text { dryer }) \\
(\%)\end{array}$ \\
\hline 8.00 & 26 & 24 & 85 & 80 \\
\hline 20.00 & 30 & 24 & 78 & 43 \\
\hline 21.00 & 30 & 24 & 83 & 52 \\
\hline
\end{tabular}

\subsection{Moisture Removal}

The rate of moisture removal per day for each of the product was presented in Figures 13 and 14. It shows that drying rate is faster in the solar dryer compare to open sun drying for all the samples. From fig 13, it took the solar dryer four days to dehydrate $1 \mathrm{~kg}$ of unripe plantain from $90 \%$ to $15 \%$, while, it took five days to dry the same quantity of plantain to the same moisture content in the open sun drying Fig. 14.

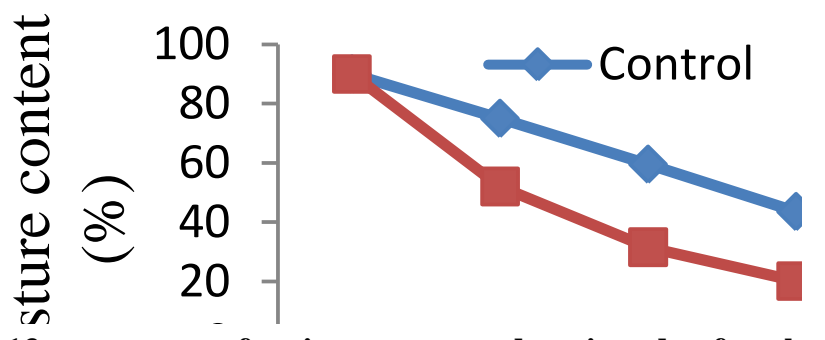

Fig:13 percentage of moisture removed against day for plantain

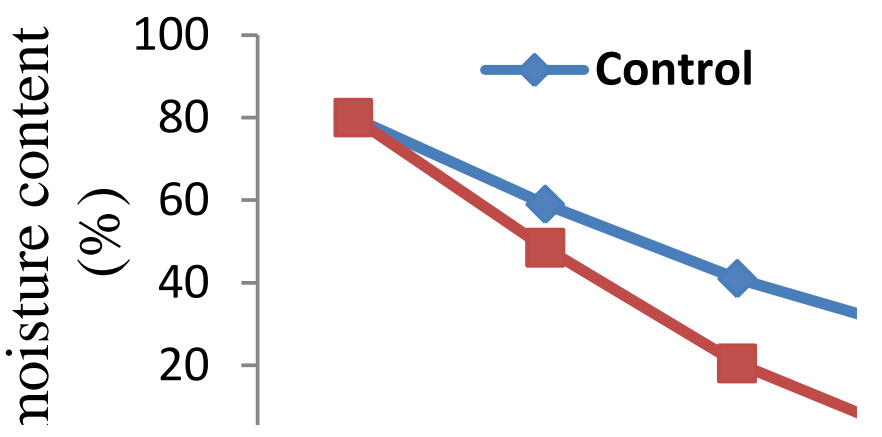

Fig: 14 Graph of percentage of moisture removed against day for OKRA

\subsection{Proximate Analysis}

Table 4 contains the results of proximate composition of unripe plantain for fresh, solar and open sun dried samples. From the table, it was observed that the result of moisture content was significantly higher for fresh sample, followed by open sun drying and the solar dryer. The protein content of the solar dried plantain was significantly higher compared to the open sun dried and slightly lower than the fresh sample. This may be attributed to the controlled and relatively higher temperature of the solar

dryer during the drying process. Results of the ash content and fibre content revealed that solar dried sample was significantly higher than the open sun drying and fresh samples. It was observed that the open sun drying samples had significantly higher fat values than the fresh and solar dryer dried samples this may be due to the direct exposure to sun.

Table 5 contains the result of proximate composition of okra for fresh, solar and open sun dried samples. The protein content of the solar dryer was significantly higher compared to the open sun drying and fresh samples. This may be attributed to the controlled and relatively higher temperature of the solar dryer during the drying process. Moisture content was significantly higher for fresh sample, followed by open sun and the solar dried samples respectively. It was observed that the open sun-drying sample had significantly higher fat values than the fresh and solar dryer samples. Crude fibre was significantly higher for solar dryer okra. This indicates that solar dried vegetables or crops contain more fibre than the open sun drying and fresh vegetables. Dietary fibre in vegetables increases bulk and reduces food transit time in the alimentary canal and the incidence of constipation and other and other related diseases [15]. 
International Journal of Advances in Scientific Research and Engineering (ijasre), Vol 6 (1), January-2020

Table: 4 DETAILED RESULTS OF THE PHYSICO CHEMICAL PROPERTIES OF Plantain (Control = Fresh produce)

\begin{tabular}{|l|l|l|l|l|l|}
\hline $\begin{array}{l}\text { Drying } \\
\text { method }\end{array}$ & $\begin{array}{l}\text { Protei } \\
\mathrm{n} \\
\text { Conte } \\
\mathrm{nt}(\%)\end{array}$ & $\begin{array}{l}\text { Fat } \\
\text { Conte } \\
\mathrm{nt} \\
(\%)\end{array}$ & $\begin{array}{l}\text { Fibre } \\
\text { Conte } \\
\mathrm{nt}(\%)\end{array}$ & $\begin{array}{l}\text { Ash } \\
\text { Conte } \\
\mathrm{nt}(\%)\end{array}$ & $\begin{array}{l}\text { Moistu } \\
\text { re } \\
\text { Conten } \\
\mathrm{t}(\%)\end{array}$ \\
\hline Solar & 3.46 & 1.86 & 10.35 & 2.23 & 14.88 \\
\hline Sun & 2.29 & 2.18 & 8.46 & 1.84 & 16.80 \\
\hline Fresh & 4.67 & 0.88 & 2.28 & 1.39 & 90 \\
\hline
\end{tabular}

Table: 5 DETAILED RESULTS OF THE PHYSICO CHEMICAL PROPERTIES OF Okra (Control $=$ Fresh produce)

\begin{tabular}{|l|l|l|l|l|l|}
\hline $\begin{array}{l}\text { Drying } \\
\text { method }\end{array}$ & $\begin{array}{l}\text { Protein } \\
\text { Content } \\
(\%)\end{array}$ & $\begin{array}{l}\text { Fat } \\
\text { Content } \\
(\%)\end{array}$ & $\begin{array}{l}\text { Fibre } \\
\text { Content } \\
(\%)\end{array}$ & $\begin{array}{l}\text { Ash } \\
\text { Content } \\
(\%)\end{array}$ & $\begin{array}{l}\text { Moisture } \\
\text { Content } \\
(\%)\end{array}$ \\
\hline Solar & 3.51 & 3.95 & 9.41 & 8.62 & 1.67 \\
\hline Sun & 2.37 & 4.05 & 7.78 & 7.09 & 2.67 \\
\hline Fresh & 5.71 & 3.93 & 2.23 & 0.94 & 80.06 \\
\hline
\end{tabular}

\section{CONCLUSION}

A solar dryer incorporating a thermal storage system was developed and its performance evaluated. The dryer was tested on no-load and on-load with plantain and okra. At an average highest ambient temperature of $32^{\circ} \mathrm{C}$, an average collector temperature of $83.5^{\circ} \mathrm{C}$ and an average drying chamber temperature of $73^{\circ} \mathrm{C}$ was recorded on no-load. Also, hourly highest temperature of $85^{\circ} \mathrm{C}$ and $75^{\circ} \mathrm{C}$ were recorded in the collector and drying chamber respectively on load. The drying time of plantain and okra were reduced by $20 \%$ with the dryer as against direct sun drying. The thermal storage was able to keep the dryer warmer at $2^{\circ} \mathrm{C}$ above the ambient during off sun hours. The physio-chemical analysis showed the dryer was able to retained higher percentage of produce in terms of protein content, fibre content, ash content, $(3.51 \%),(9.31 \%),(8.62 \%)$ for plantain and $(3.46 \%),(10.35 \%),(2.23 \%)$ for okra respectively, as against $(2.37 \%),(7.78 \%),(7.09 \%)$, for okra and $(2.29 \%)$, $(8.46 \%),(1.84 \%)$ of plantain for direct sun drying.

The following conclusion was drawn

(1) The passive solar dryer was more effective

(2) It reduces drying time

(3) It produces hygienic and nutritional food products. This was evidence in the nutritional analysis carried out.

\section{RECOMMENDATION}

All seasonal evaluation of the dryer is recommended to have a full year data.

\section{REFERENCES}

[1] Cao G., Sofic E., Prior R.L. (1996): Antioxidant activity of tea and common vegetables. J Agric. Food Chem 44:3426- 3431.

[2] Velioglu Y.S., Mazza G., Gao L. and Oomah B. D. (1998). Antioxidant activity and total phenolics in selected fruits, vegetables and grain products. J Agri Food Chem 46:4113- 4117.

[3] Liberty J. T. (2014): Design, construction and performance evaluation of a postharvest heat storage solar energy crop dryer.Report submitted in partial fulfillment of the requirement for the award of the degree of master of engineering (m.eng) in the department of agricultural and bioresources engineering, faculty of engineering university of Nigeria, Nsukka. (Unpublished) 
International Journal of Advances in Scientific Research and Engineering (ijasre), Vol 6 (1), January-2020

[4] FAO, (2009). Food and Agriculture Organization of United Nations, Rome, Current Agricultural Situation-Facts and Figures.

[5] Nabilah H. (2012): Development of solar dryer system for food drying purposes. Report submitted in partial fulfillment of the requirements for the award of Bachelor of Mechanical Engineering, University of Malaysia. (Unpublished)

\{6] Ikejiofor, I.D. (1985): Passive solar cabinet dryer for drying agricultural products. In: O.Awe (Editor), African Union of Physics. Solar Energy Conversion, University of Ibadan, Nigeria, pp. 15765.

[7] Oghenenona D.E and Yusuf M.O (2011): Design and fabrication of a direct convection solar Dryer for Topioca. Journal of practices and technology. Pg 95-104.

[8] Bansal N. K., Boettcher A., and Uhlemann R. (1990). "Performance of plastic solar air heating collectors with a porous absorber," International Journal of Energy Research, vol. 7, no. 4, pp. 375384, 1983. View at Google Scholar · View at Scopus (1990).

[9] Akinola, A.O. (1999): Development and Performance Evaluation of a Mixed-Mode Solar Food Dryer. M. Eng. Thesis, Federal University of Technology, Akure, Nigeria.

[10] Stoecker, W. F, and Jones, J. W.(1982): Refrigeration and Air Conditioning, McGraw-Hill, New York.

[11] Ezekoye B, A and Enebe O.M (2006): Development and performance evaluation of modified integrated passive solar grain dryer. The Pacific Journal of Science and Technology, 2: 185-190 fish drying systems.

[12] Jinshah B.S and Ajith K.R. (2014).Structural and Thermal Analysis of Asphalt Solar Collect Using Finite Element Method. Journal of Energy Volume (2014), Article ID 602087, 9 pages

[13] Adegoke, C.O. and Bolaji, B.O. (2000): Performance evaluation of solar-operated thermosyphon hot water system in Akure. International Journal of Engineering and Engineering Technology. 2(1); 35 40

[14] Onigbogi I.O., Sobowale, S. S. and Ezekoma, O.S (2012): Design, construction and evaluation of a small scale solar dryer. Journal of Engineering and Applied Science Volume 4, June 2012.

[15] Ifon ET, Bassir O, Latunde-Dada G.O .2009. The nutritive value of some Nigeria leafy vegetables. Part 1, Vitamin and mineral content. Food Chem., 3: 267- 350.

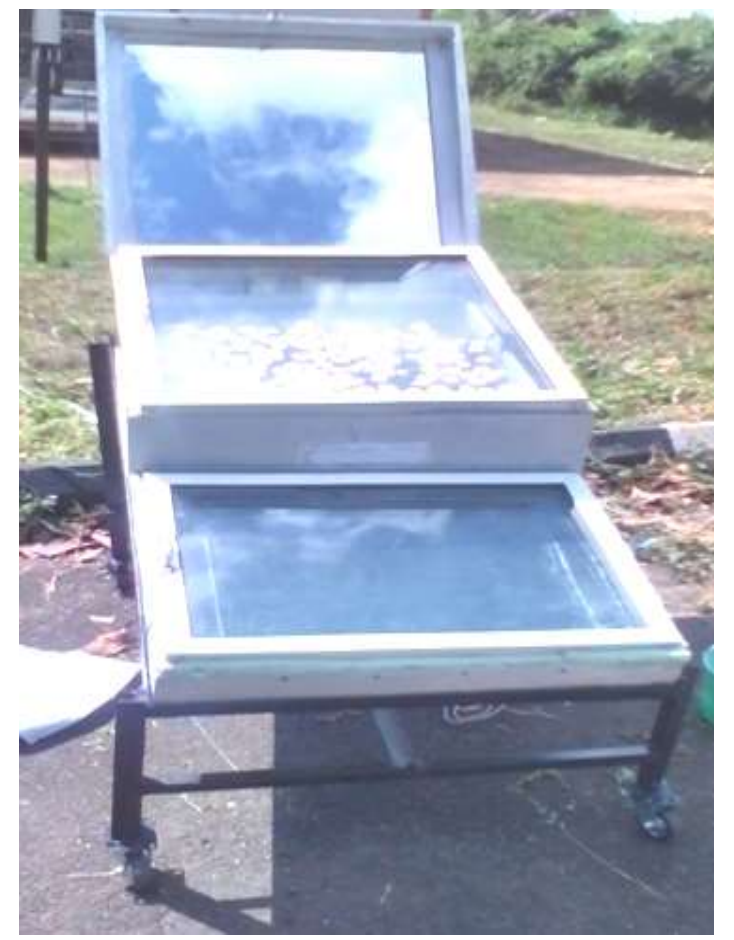

Pictorial View of the constructed Solar Dryer 
International Journal of Advances in Scientific Research and Engineering (ijasre), Vol 6 (1), January-2020

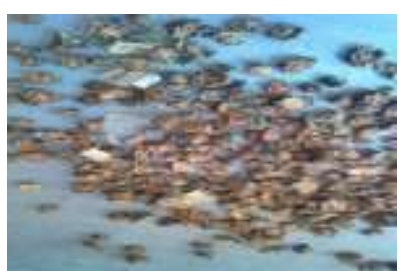

Solar Dried Okra

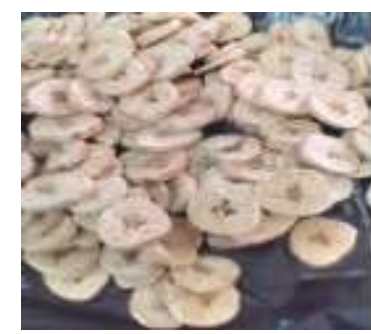

Open Sun dried for Plantain

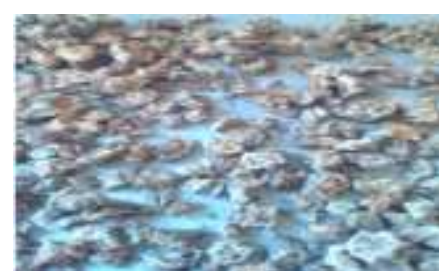

Open Sun Dried for Okra

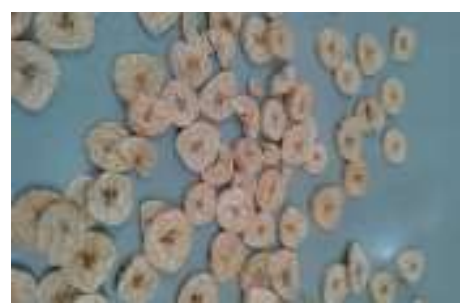

Solar Dried Plantain 